\title{
焼なましおよび表面圧延低炭素鋼の 疲労き裂伝ぱ挙動*
}

\author{
The Fatigue Crack Propagation Behavior of the Annealed \\ and the Surface-Rolled Low Carbon Steel \\ by \\ Akira YoshiDA \\ (Faculty of Engineering, Okayama University, Okayama) \\ Hideaki KAWABE and Tomoharu YAMADA \\ (Faculty of Engineering, Osaka University, Suita)
}

吉田彰** 川辺秀昭***山田朝 治****

In order to clarify the behaviors of low carbon steels, the annealed and the surface-rolled, in their propagation of fatigue crack, the microfractographic observation of the specimens both of these descriptions of materials, has been performed by the electron microscopic replica method, with particular respect to their fatigue fractured surfaces. The results of the observation have been fully discussed, and the macroscopic investigation has been made of the specimens concerning their behaviors in propagation of fatigue crack.

The results are summarized as follows :

(1) The fatigue crack propagation rate in the surface-rolled specimen is undoubtedly slower than in the annealed specimen.

(2) The spacing in striation on the fatigue fractured surface in both the sorts of specimens is larger than what was first estimated from the fatigue crack propagation rate, $d l / d N$. This fact shows that there is the latent period in the fatigue crack propogation process in both the sorts of specimens.

(3) The various patterns observed on the fatigue fractured surfaces are similar in both the sorts of specimens, therefore the fatigue fracture mechanism in both the sorts of specimens is considered to be essentially the same.

(4) The platy on the fatigue fractured surface in the surface-rolled specimen is smaller in size than that in the annealed sort, and the striation on the platy in the surface-rolled specimen runs in locally different direction from the main crack propagation line. It can be considered from these facts that in the surface-rolled specimen there have been formed, in consequence of micro internal stress in the work hardened surface layer, branched microcracks at the tip of the main fatigue crack.

(5) The slower fatigue crack propagation rate in the surface-rolled specimen is due to the longer latent period that has come, so it is considerd, from the structural difference between the annealed specimen and the surface-rolled specimen, and also from the stress relaxation at the branched crack tip in the surface-rolled specimen.

(Received July 30, 1970)

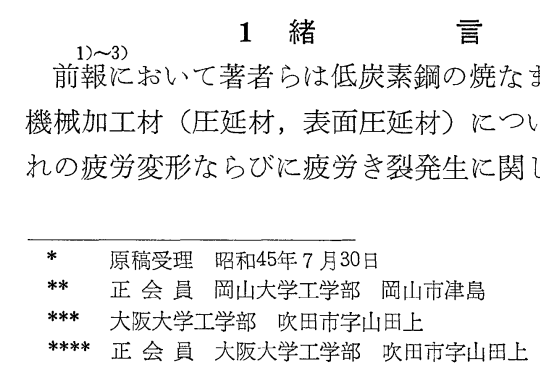

追求し，それらの機構を明らかにしてきたが，これら 疲労き裂発生を含さそれ以前の疲労に関する問題とと もに, それに続く疲労き裂伝ぱの問題が重要な課題と なってくる。この疲労き裂伝ぱ挙動の解明にあたり, 近年，巨視的な研究とともに electron-fractography がその研究手段として用いられるようになってきた。

本報告に执いては低炭素鋼の焼なるし材および表面 圧延材を用いて, これらの疲労き裂伝ぱ挙動を明らか 
にするため, 疲労破面の fractography より観察され る striation の間隔や方向，さらに破面に形成される pattern などの局部的な相違は材料の微視的組識がき 裂伝ぱ速度に影響することを示していると考えられる ので，両者について巨視的な疲労き裂伝ぱ速度の測定 とともに, electron-fractography の観察をも行なっ た。

\section{2 実 験 方 法}

疲労き裂伝ぱ過程を観察するにあたり，用いた試験 片はFig. 1 に示す形状，寸法のものである。この試験 片の素材は一般構造用圧延鋼材 (SS 41) で, その化学

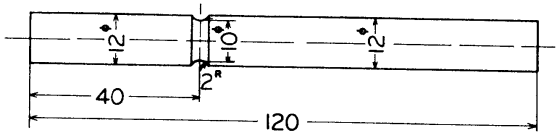

Fig. 1. Form and size of the specimen for rotary bending fatigue test (Stress concentration factor $\alpha=1$. 48).

Table I. Chemical composition (\%) of specimen.

\begin{tabular}{c|c|c|c|c}
\hline $\mathrm{C}$ & $\mathrm{Mn}$ & $\mathrm{S}_{1}$ & $\mathrm{P}$ & $\mathrm{S}$ \\
\hline 015 & 046 & 023 & 0019 & 0023 \\
\hline
\end{tabular}

Table II. Mechanical properties of specimen

\begin{tabular}{c|c|c|c}
\hline $\begin{array}{c}\text { Yield strength } \\
\left(\mathrm{kg} / \mathrm{mm}^{2}\right)\end{array}$ & $\begin{array}{c}\text { Tens1le strength } \\
\left(\mathrm{kg} / \mathrm{mm}^{2}\right)\end{array}$ & $\begin{array}{c}\text { Elongation } \\
(\%)\end{array}$ & $\begin{array}{c}\text { Reduction of } \\
\text { area (\%) }\end{array}$ \\
\hline 255 & 404 & 397 & 660 \\
\hline
\end{tabular}

成分は Table I に示すとおりであり，焼なまし後の 静機械的性質は Table II に示すと拈りである. 熱処 理としては，素材をFig. 1 に示す試験片に機械加工後, $920^{\circ} \mathrm{C} \times 24 \mathrm{hr}$ ．真空中完全嗦なましを行ない，前加工 の影響を取り去ると同時にフェライト結晶粒の平均直 径を約 $150 \mu$ にた。そして焼なまし材は完全焼なま 乙後，そのために生じた脱炭層の除去叔よび良好な面 をえるため電解研摩を行なった。一方表面圧延材は完 全焼なまし後, 電解研摩にて脱炭層を除去し, 環状み ぞ表面圧延機を用いて圧延圧力 $100 \mathrm{~kg} / \mathrm{mm}^{2}$ にて表面 圧延し，その後仕上げ研摩を軽く行なった．表面圧延 材のかたさ分布曲線は前報に示したと拉りであり，加 工層深さは約 $1 \mathrm{~mm}$ である。

疲労破面の観察は焼なまし材和よび表面圧延材の両 者につき, 試験片の切欠き底表面から中心へ約 $400 \mu$ までレプリカ法電子顕微鏡にて連続的に行なった。な お，用いた電子顕微鏡は日本電子製 Super Scope (加 速電圧 $30 \mathrm{kV}$ ) 和よび $6 \mathrm{AS}$ 型 (加速電圧 $100 \mathrm{kV}$ ) である。

またこれより先に，これら焼なまし材，表面圧延材 の両者につき, それぞれのき裂伝ぱ曲線を求めたが,

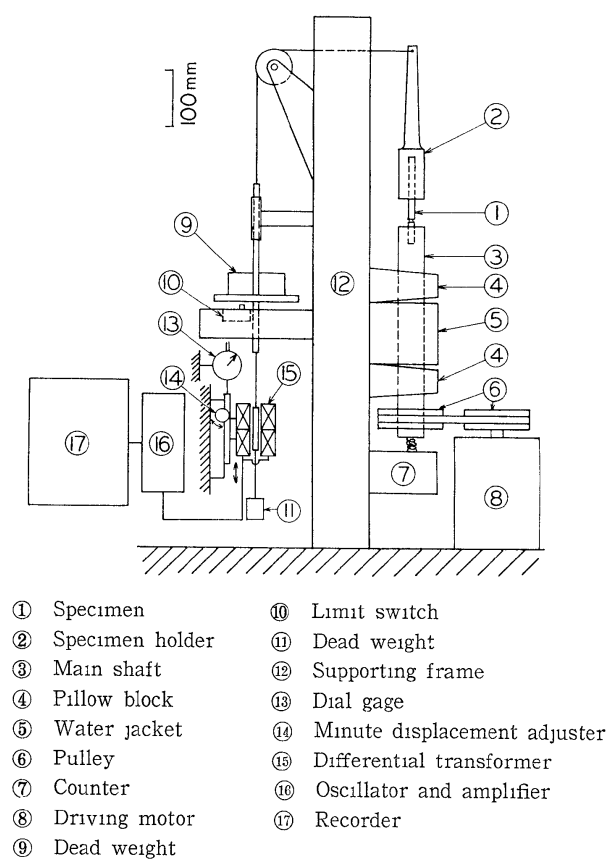

Fig 2. Apparatus for the measurment of crack length in specimen during fatigue.

そのための装置をFig. 2 に示す. 試験機は片持回転曲 げ疲労試験機（1800 r.p.m.）で，この試験機を用い て求めた疲労強度と小野式回転曲げ疲労試験機 (3600 r.p.m.)を用いての前報の結果とは時間強度において はほとんど一致し疲労限度はまったく一致した。疲労 過程中のき裂伝ぱ曲線は荷重端でのたわみを測定する ことにより求めた。すなわら,たわ久測定装置は差動 トランスを用いた変位計と電子管自動平衡式記録計を 組み合わせて, 荷重端の変位を試験中連続的に記録で きるようにしたもので，この装置を用いて一定応力の もとで数本の切欠き試験片の疲労試験を行ない，その たわ久量の測定から，あらかじめ求めた，疲労き裂長 さ（加熱着色によって実測した平均き裂長さ）一たわ 久曲線を利用して各試験片のき裂長さを連続的に求め た。

\section{3 実験結果および考察}

疲労き裂伝ぱ過程の挙動を調べるために用いた応力 レベルは $\sigma=25 \mathrm{~kg} / \mathrm{mm}^{2}$ である。この応力レベルに 扣いて焼なまし材和よび表面圧延材の疲労寿命はそれ それれ $N=10^{5}$ および $N=2 \times 10^{5}$ である。すなわち一 般に応力レベルにより疲労機構が変わると考えられる が，ここで用いたような低炭素鋼のさ裂伝ぱに関して は，そのき裂が進展性のものであれば，すなわち応力 レベルが Wood のいう $S-N$ 曲線の $H$ 領域であれば, 応力レベルの大小により，その機構に大差はないと考 えられる。それゆえここでは前報の $S-N$ 曲線を参照 
して, 応力レベルは 1 種類とした.

\section{$3 \cdot 1$ 疲労き裂伝ぱ曲線}

Fig. 3 はig. 2 に示した実験装置を用い，たわみ測 定法により求めた, 繰返し応力 $\sigma=25 \mathrm{~kg} / \mathrm{mm}$ での, き裂長さと荷重端のたわ文の関係を示している。これ から明らかなように焼なまし材，表面圧延材の両者は 小さなばらつきをもって，同一の直線上にあることが わかる.Fig. 4 はFig. 3 の関係を用いて求めた，焼な まし材扣よび表面圧延材の疲労き裂伝ぱ曲線である。 また Table III は各き裂長さでの焼なまし材执よび 表面圧延材のき裂伝ぱ速度を，Fig. 4 亿示すき裂伝ぱ 曲線の接線こう配より求め, 示したものである。これ

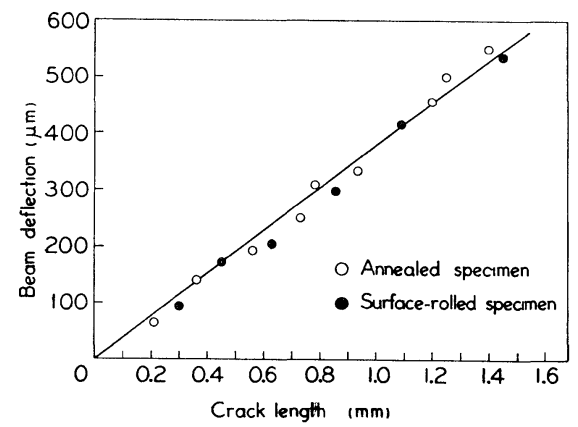

Fig. 3. Relationship between crack length and beam deflection for rotary bending fatigue specimen at $\sigma=25 \mathrm{~kg} / \mathrm{mm}^{2}$.

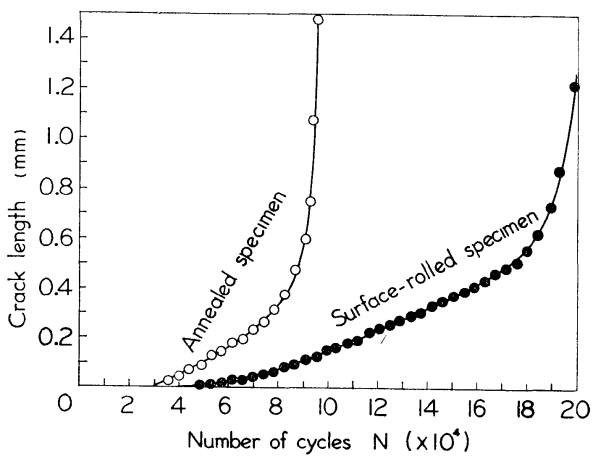

Fig. 4. Crack propagation curves for rotary bending fatigue specimen at $\sigma=25 \mathrm{~kg} / \mathrm{mm}^{2}$.

Table III. Crack propagation rate for rotary bending fatigue specimen at $\sigma=25 \mathrm{~kg} / \mathrm{mm}^{2}$.

\begin{tabular}{c|c|c}
\hline $\begin{array}{c}\text { Crack length } \\
(\mathrm{mm})\end{array}$ & \multicolumn{2}{|c}{ Crack propagation rate $d l / d N(\mathrm{~mm} /$ cycle $)$} \\
\cline { 2 - 3 } 0.11 & Annealed specimen & Surface-rolled specimen \\
0.28 & $060 \times 10^{-5}$ & $036 \times 10^{-5}$ \\
046 & $089 \times 10^{-5}$ & $043 \times 10^{-5}$ \\
063 & $264 \times 10^{-5}$ & $065 \times 10^{-5}$ \\
080 & $590 \times 10^{-5}$ & $167 \times 10^{-5}$ \\
1.06 & $1050 \times 10^{-5}$ & $328 \times 10^{-5}$ \\
& $1750 \times 10^{-5}$ & $650 \times 10^{-5}$ \\
\hline
\end{tabular}

らより, 表面圧延材の加工層深さ，すなわら試験片切 欠き底表面より中心へ $1 \mathrm{~mm}$ までについての両者の 疲労さ裂伝ぱ挙動を比較すると明らかな表面圧延材の き裂伝ば速度は焼なまし材の場合より小さな值をとっ ている。

一般に疲労き裂伝ぱ速度 $d l / d N(l$ ：き裂長さ， $N$ : 応力繰返乙数) は Stress Intensity Factor, Kを用 いて, $d l / d N=C K^{m}$ なる形で表わされることが知られ ているが，Fig. 5 は Harris が切欠きを有する回転曲 げ疲労試験片の任意の長さりき裂について求めている 次式を用いて，焼なまし材执よび表面圧延材雨者の $K$ 值を各き裂長さに対して求めた結果をそれぞれのき裂 伝ぱ速度に対してプロットしたものである.

$$
K=\frac{4 M}{\sqrt{\pi a^{5}}} \cdot \sqrt{\frac{t}{\frac{4}{5} a+\frac{64}{9} \mathrm{t}}}
$$

ここで $K$; Stress intensity factor $\left(\mathrm{kg} / \mathrm{mm}^{3 / 2}\right)$

$t$; き裂長さ十切欠き深さ $(\mathrm{mm})$

$a ； き$ 裂底から試験片中心までの距離 $(\mathrm{mm})$ $M$; 曲げモーメント $(\mathrm{kg} \cdot \mathrm{mm})$

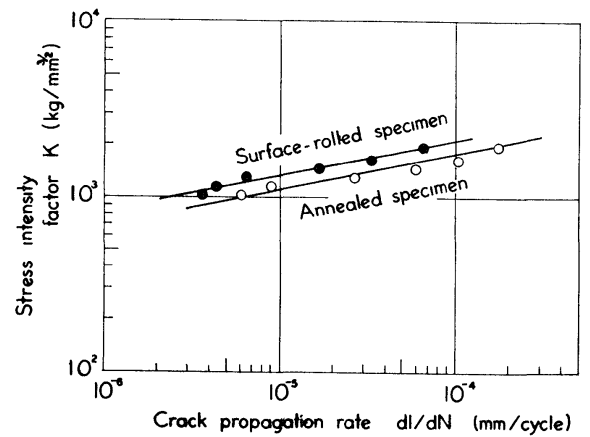

F1g. 5. Relationship between crack propagation rate and stress intensity factor for rotary bending fatigue specimen.

Fig. 5 より，焼なまし材と表面圧延材に特いて $m$ 值は 両者とも汪とんど同じであるが，C值浪面圧延材の 方が焼なるし材の場合より小さな值をとっていること が明らかである。このように表面圧延材に拉けるC值 がより小さくなり，疲労き裂伝ぱ速度が沶そいのは， き裂先端での両者のき裂の形態の微視的な相違ならび に材質および疲労過程中のその変化の相違に依存して いると考光られる。な和Fig. 5 にプロットしてある丸 印は Table III に示した各き裂長さに対して(1)式よ り求めたK值を，それぞれのき裂長さに打けるき裂伝 ぱ速度をFig. 4 のき裂伝ぱ曲線の接線こう配より求め てえた值に対して，焼なまし材扝よび表面圧延材につ きプロットしたものである。

以上のような焼なまし材と表面圧延材に和ける巨視 的な疲労き裂伝ぱ挙動の相違を微視的に明らかにする 
ため，以下に electron-fractography の観察 を行なった。

\section{$3 \cdot 2$ Electron-Fractography の観察}

疲労き裂伝ぱの過程をみるために疲学破面 の観察を行なった結果をFig. 6,7 和よびFig. 8 に示す. Fig. 6 扰よび Fig. 7 は切欠き回転 曲げ疲労試験片について，その切欠き底表面 から中心部に向か⿰て，表面圧延による加工 硬化檿が允分に存在している表面層 $0 \sim 400 \mu$ での焼なまし材执よび表面压延材の場合の electron-fractography の連続写真である。 またFig. 8 は両材料について部分的にさらに 高倍率で観察したものである。

これら痩労破面上にみとめられる波状の縞 模様は striation とよばれ，この striation の 1 ピッチが繰返し応力の 1 サイクルに対応 することが和もにアルミニウム合金について 確認され，裂伝ぱ過程の解析に実用されて いるが，本実験に用いた低炭素鋼などの鉄鋼 材料に特いては Fig. 6，7 和よび Fig. 8 そみ られるように， striation の間隔はかなりま ち秀らで, striation 自体アルミニウム合金 の場合と比較するとあまり明確でない、それ ゆ光，鉄鋼材料に沶いては striation の数と 繰返し応力のサイクル数の関係は今日まだあ まり明らかにされていないが，德田によると 炭素鋼の場合， striation の 1 ピッチは応力 の繰り返し10回のオーダーに対応しているこ 報告して特り，木実験結果に拈いても，Fig 4, Table III とFig. 6, 7 および Fig. 8 の比 較より，1つの striation を形成するのに 1 回以上の応力繰返乙数を要していることは明 らかであり，この事実は疲労き裂伝ぱ過程に おいて潜在期間があることを示している。

Fig. 6 と Fig. 7 の比較およびFig. 8 (a) と Fig. 8 (b) の比較より， striation の間隔が焼なま 乙材と表面圧延材とであまり㾏がないことか ら，表面压延材に特いて疲学き裂伝ぱ速度が 颃そくなるのは，この疲労き裂伝ぱにおける 潜在期間が焼なるて材に和けるより長いと考 えられ，またこれは筧なま乙材と表面圧延材 に特ける材質の相違に依存していると考えら れる。さらに焼なまし材之表面圧延材との疲 労破面には，両者ともよく似た種々の pat tern がみられ，この両者の疲労破壤形式は 本質的には同じすのであると考えられるが， ただ試験片切欠き底表面より中心へ $300 \mu \sim$ $350 \mu$ の破面で両者を比較すると表面圧延材

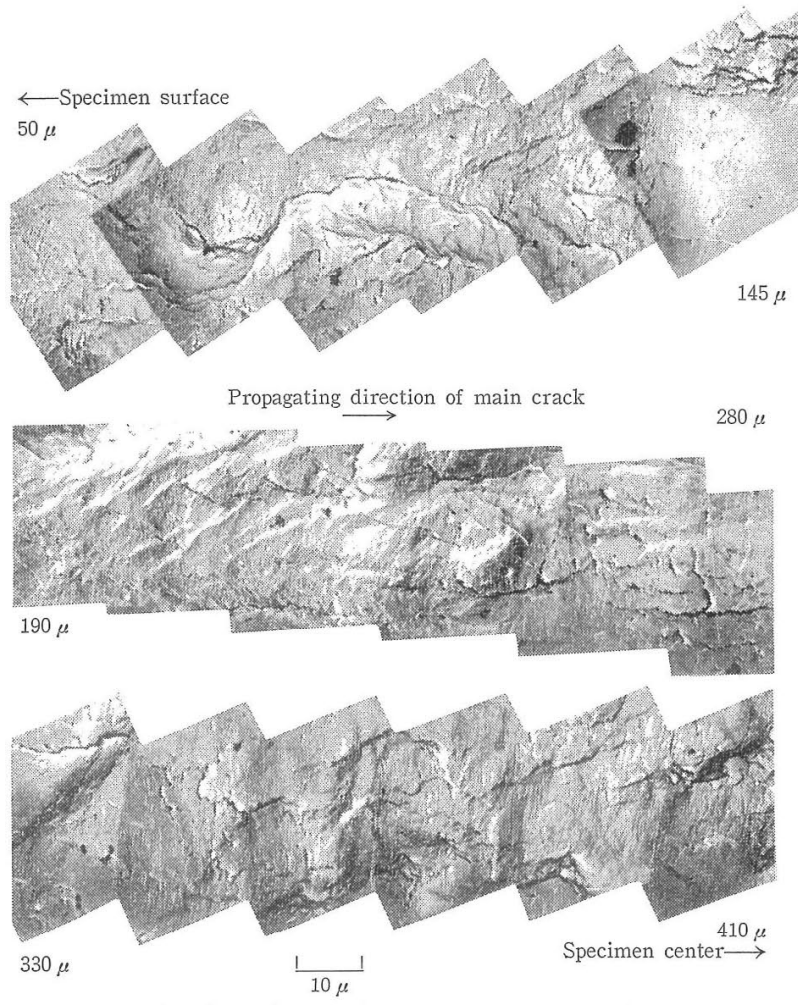

Fig. 6. Electron-fractography on annealed specimen under rotary bending fatigue test at $\sigma=25 \mathrm{~kg} / \mathrm{mm}^{2}$.
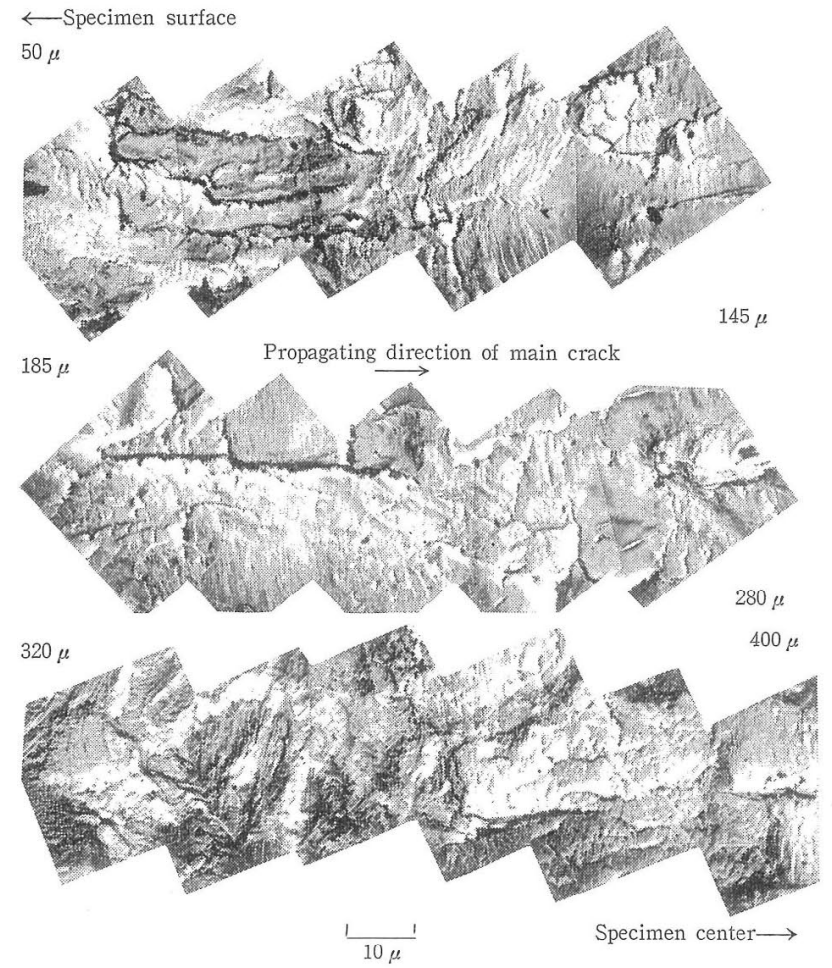

Fig. 7. Electron-fractography on surface-rolled specimen under rotary bending fatigue test at $\sigma=25 \mathrm{~kg} / \mathrm{mm}^{2}$ 
そ挄いては platy の大きさは小さく platy 上の striation の方向は主き裂の方向と著し く異なっている。このことにより表面圧延材 に和いては谷の表面加工層中の微視的な内部 応力により，き裂がその先端で微視的枝分れ を生じていると考光られ，この枝分れにより き裂先端で応力緩和が拍こっていると考克ら 扎る。

以上の上5に, 燒なまし材と表面圧延材に ついての electron-fractography の観察より， 表面圧延材江特いて疲学き裂伝ぱ速度が招气

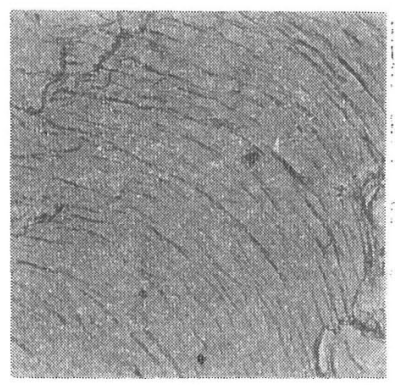

(a)

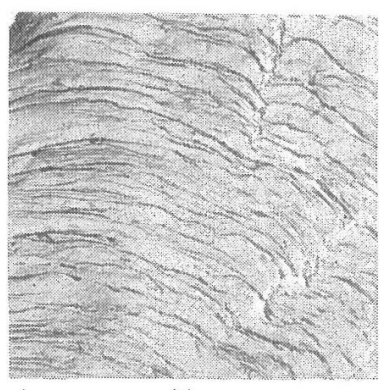

(b)

Fig. 8. Electron-fractography for (a) annealed specimen and (b) surface-rolled specimen.

おけ名応力緩和に依存し, 疲労党裂伝ばにおける潜在 期間が焼なさし材より長くなるからで离ると考えられ た。

終わりに本報告をあえめるにあたりご支援を与えら れた岡山大学工学部藤田公明教授に感謝の意を表しま 于.

(昭和43年 9 月 3 日 第12回材料研究連合絴演会にて講演)

低炭素鋼焼なむし材および表面压延材の疲労き裂伝 ぱ挙動における画者の相違, 相似点を明らかにするた め，巨視的な疼労き裂伀ぱ挙動を明らかにするととも に, electron fractography の観察にて微視的に両者 の疲労き裂伝ぱ挙動の比較，検討を行なった。それら 要約すると次の上らに要る。

（1）表面圧延材の疲労き裂伝ぱ速度は同一応力振幅 に执いて，焼なまし材のそれより明らかに低くなった。

（2）焼なまし材および表面圧延材とも并の破面上の striation の 1 ピッチの間隔はき裂伝ぱ速度 $d l / d N$ よ

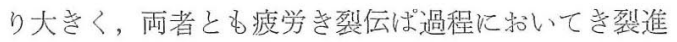
展の潜在期間があることを亦した。

（3）また焼なまし材と表面圧延材との痁学破断面に は両者ともよく似た種々の pattern が観察导れ, 両者 の疲労破壞形式は本質的に同じものであると考学られ た。

（4）表面圧延材に拈いては破面上の platyの大きさ は小さく, platy 上の striation の方向は主さ裂の方 向と著しく異なっていた。このことより表面压延材に 扣いては, 去の表面加工層中の微視的な内部応力によ りさ裂の枝分れを生していることが推論された。

（5）表面压延材に括いて疲労き裂伝ぱ速度が抢そい のは，焼なむし材と表面圧延材における材質的相違な らびに表面圧延材のき裂の枝分れのためのき裂先端に

\section{参考 文 献}

1) 吉田 彰, 上村正雄, 川辺秀昭, 山田朝治, 材料, 18, 1106 (1969).

2）吉田 彰, 川辺秀昭, 田中政夫, 津和秀夫, 材料, 19, 722 (1970).

3）吉田 彰, 川辺秀昭, 山田朝治, 材料, 19, 795 (1970).

4) 吉田 彰, 田中政夫, 津和秀夫, 材料, 18, 695 (1969).

5) Wood, W. A., et al., Trans. AIME., 230, 511 (1964).

6) Irwin, G. R., et al., "Fracture Toughness Testing and Its Applications", ASTM., STP. No. 381, 84(1965).

7) Paris, P.C., et al., Trans. ASME. Ser. D, 85, 528 (1963)

8) Kraft, J. M., Trans. ASM., 58, 691 (1965).

9）小林英男, 中沢 一, 材料, 18, 627 (1969).

10) Harris, D. O., Trans. ASME. Ser. D, 89, 49 (1967).

11）福永秀春, 博士論文 (大阪大学) (1968).

12) Forsyth, P. J. E., Acta Met., 11, 703 (1963).

13）山田敏郎，北川 茂，材料，18，689（1969）。

14）小寺沢良一, 志茂大治郎, 日本機械学会論文集, 36 , 904 (1970).

15) 徳田 昭, 日本金属学会誌, 24, 171 (1960).

16）横堀武夫，日本機栈学会誌，70，1258（1967）.

17) Jacoby, G., Expl. Mech., 5, 65 (1965). 